Check for updates

Cite this: RSC Adv., 2017, 7, 55081

\title{
Synthesis and characterisation of $\mathrm{SrY}_{2-x} \mathrm{Ce}_{x} \mathrm{O}_{4}$ as environmentally friendly reddish-brown pigments
}

\author{
Ryohei Oka, Yusuke Shobu, Fumiya Aoyama, Takashi Tsukimori \\ and Toshiyuki Masui (D)*
}

Reddish-brown $\mathrm{SrY}_{2-x} \mathrm{Ce}_{x} \mathrm{O}_{4}(0 \leq x \leq 1.2)$ solid solutions were synthesized by a citrate sol-gel method as novel environmentally friendly inorganic pigments. The powders obtained were characterized by $X$-ray powder diffraction (XRD), UV-vis diffuse reflectance spectra and $\mathrm{CIE} L^{*} a * b * C h^{\circ}$ chromatic coordinate measurements. All $\mathrm{SrY}_{2-x} \mathrm{Ce}_{x} \mathrm{O}_{4}(0 \leq x \leq 1.2)$ samples were obtained in a single-phase form and the lattice volume increased on increasing the $\mathrm{Ce}^{3+}$ concentration. The reddish-brown pigments exhibited optical absorption due to the $4 \mathrm{f}-5 \mathrm{~d}$ allowed transition of $\mathrm{Ce}^{3+}$. The absorption bands observed in the wavelength region of 400 and $550 \mathrm{~nm}$ were due to the $\mathrm{Ce}^{3+}$ ions in the ideal octahedral $\mathrm{Y}^{3+}$ site and those in the longer wavelength region above $600 \mathrm{~nm}$ were attributed to the transition of $\mathrm{Ce}^{3+}$ in the distorted octahedral $\mathrm{Y}^{3+}$ site. The samples gradually became reddish on increasing the $\mathrm{Ce}^{3+}$ content. The most reddish colour was obtained in $\mathrm{SrYCeO}_{4}\left(a^{*}=+21.8\right)$.

Received 15th September 2017 Accepted 27th November 2017

DOI: 10.1039/c7ra10250j

rsc.li/rsc-advances

level of the $5 \mathrm{~d}$ orbital of $\mathrm{Ce}^{3+}$ is strongly affected by the crystal

\section{Introduction}

Inorganic pigments are typically applied to ceramic tiles, inks and paints, due to their high hiding power, weather resistance and thermal stability. However, the use of the conventional pigments containing toxic elements, such as $\mathrm{Cd}, \mathrm{Pb}, \mathrm{Hg}, \mathrm{Cr}, \mathrm{Co}$, and $\mathrm{Sb}$, has been forbidden or restricted, because they have adverse effects on the human body and the environment. Therefore, a number of non-toxic inorganic pigments have been reported by several researchers in order to replace the toxic pigments with the environmentally-friendly or less-toxic ones. ${ }^{\mathbf{1 - 1 7}}$ In particular, development of novel red pigments has been required and several studies have been reported. ${ }^{18-27}$ Among them, it has been reported that $\mathrm{Ca}_{1-x} \mathrm{La}_{x} \mathrm{TaO}_{2-x} \mathrm{~N}_{1+x}$ and $\mathrm{Ce}_{2} \mathrm{~S}_{3}$ showed bright red colour. ${ }^{\mathbf{1 8 , 1 9}}$ But, unfortunately, harmful $\mathrm{NO}_{x}$ and $\mathrm{SO}_{x}$ are generated when these nitride and sulphide pigments are incinerated. Therefore, oxides are desirable as materials for environmentally friendly pigments.

Because of this situation, we focused on a trivalent cerium $\left(\mathrm{Ce}^{3+}\right)$ ion as a red colouring source. As an example of a popular $\mathrm{Ce}^{3+}$-containing material, $\mathrm{Ce}^{3+}$-doped yttrium aluminium garnet, $(\mathrm{Y}, \mathrm{Ce})_{3} \mathrm{Al}_{5} \mathrm{O}_{12}\left(\mathrm{YAG}_{\mathrm{C}} \mathrm{Ce}^{3+}\right)$, has been well known as a yellow-emitting phosphor widely used in white light emitting diodes. YAG: $\mathrm{Ce}^{3+}$ absorbs the visible lights in the wavelength region of 410 to $500 \mathrm{~nm},{ }^{28-30}$ which is attributed to the $4 \mathrm{f}-5 \mathrm{~d}$ allowed transition. The absorption wavelength due to the $\mathrm{Ce}^{3+}$ ions depends on the host crystal structure, because the energy

Department of Chemistry and Biotechnology, Graduate School of Engineering, Tottori University, 4-101, Koyama-cho Minami, Tottori 680-8552, Japan. E-mail: masui@ chem.tottori-u.ac.jp; Fax: +81-857-31-5264; Tel: +81-857-31-5264 field strength around the $\mathrm{Ce}^{3+}$ ions. In the case of a phosphor, the amount of $\mathrm{Ce}^{3+}$ is about $1 \mathrm{~mol} \%$ to prevent concentration quenching, but it is considered that colouring of the sample can be seen by further increasing the $\mathrm{Ce}^{3+}$ concentration. Furthermore, it is expected that strong reddish colour will be obtained if $\mathrm{Ce}^{3+}$ is doped at a high concentration in the $\mathrm{Y}^{3+}$ site in the lattice with a stronger crystal field.

In this study, we selected $\mathrm{SrY}_{2} \mathrm{O}_{4}$ as a host material, because this compound is composed of non-toxic elements. $\mathrm{SrY}_{2} \mathrm{O}_{4}$ belongs to the $\mathrm{CaFe}_{2} \mathrm{O}_{4}$-related structure, and it crystallizes into an orthogonal structure with space group Pnma. Four formula units for a total of 28 atoms are contained in the $\mathrm{SrY}_{2} \mathrm{O}_{4}$ structure. All of the constituent atoms occupy $4 \mathrm{c}$ sites according to the Wyckoff notation. ${ }^{31}$ The $\mathrm{Sr}^{2+}$ and $\mathrm{Y}^{3+}$ ions are coordinated by eight and six $\mathrm{O}^{2-}$ ions, respectively. $\mathrm{Y}^{3+}$ occupies two nonequivalent sites $C_{\mathrm{s}}$ symmetry, where one $\mathrm{Y}(1)$ site is nearly a regular octahedron but the other $\mathrm{Y}(2)$ one is much distorted. ${ }^{32}$ Since it has been reported that high calcination temperature is necessary for the synthesis of $\mathrm{SrY}_{2} \mathrm{O}_{4}$ by a solid-state reaction, ${ }^{3,34} \mathrm{SrY}_{2-x} \mathrm{Ce}_{x} \mathrm{O}_{4}(0 \leq x \leq 1.2)$ pigments were synthesized using a citrate sol-gel method. The optical and colour properties of the samples were evaluated as novel environmentally friendly inorganic reddish-brown pigments.

\section{Experimental}

\section{Materials and methods}

The $\mathrm{SrY}_{2-x} \mathrm{Ce}_{x} \mathrm{O}_{4}(0 \leq x \leq 1.2)$ pigments were synthesized using a citrate sol-gel method. $\operatorname{Sr}\left(\mathrm{NO}_{3}\right)_{2}$ (Wako Pure Chemical Industries Ltd., 99.9\%), $\mathrm{Y}\left(\mathrm{NO}_{3}\right)_{3} \cdot 6 \mathrm{H}_{2} \mathrm{O}$ (Kishida Chemical Co. 
Ltd., 99.9\%) and $\mathrm{Ce}\left(\mathrm{NO}_{3}\right)_{3} \cdot 6 \mathrm{H}_{2} \mathrm{O}$ (Kishida Chemical Co. Ltd., 98.0\%) were weighed so as to obtain the objective compositions and dissolved in deionized water to adjust the $\mathrm{Sr}$ and $(\mathrm{Y}+\mathrm{Ce})$ concentrations to 0.3 and $0.6 \mathrm{~mol} \mathrm{~L}^{-1}$, respectively. After the solution was stirred homogeneously, citric acid was added as a chelating agent to complex the cations into the solution in the mole ratio $2: 1$ with respect to the total cations ( $\mathrm{Sr}, \mathrm{Y}$ and $\mathrm{Ce}$ ). The mixed solution was stirred at $80{ }^{\circ} \mathrm{C}$ until a gel was obtained, and then, the gel was dried at $120^{\circ} \mathrm{C}$ for $24 \mathrm{~h}$ in an oven. The dried gel was calcined in an aluminium silicate (mullite) crucible at $500{ }^{\circ} \mathrm{C}$ for $6 \mathrm{~h}$ in air. After the calcination, the sample was heated again at $1300{ }^{\circ} \mathrm{C}$ for $6 \mathrm{~h}$ in a flow of $5 \% \mathrm{H}_{2}-95 \% \mathrm{~N}_{2}$ gas. Before characterisation, the sample was ground in an agate mortar.

\section{Characterisation}

The samples synthesized were characterised by X-ray powder diffraction (XRD; Rigaku, Ultima IV) with $\mathrm{Cu}-\mathrm{K} \alpha$ radiation, operated with voltage and current settings of $40 \mathrm{kV}$ and $40 \mathrm{~mA}$, respectively. The sampling width and the scan speed were $0.02^{\circ}$ and $6^{\circ} \mathrm{min}^{-1}$. The lattice parameters and volumes were calculated from the XRD peak angles, which were refined using $\alpha$ $\mathrm{Al}_{2} \mathrm{O}_{3}$ as a standard and using the CellCalc Ver. 2.20 software. Rietveld refinement of the obtained XRD patterns was performed using the RIETAN-FP software package to determine the precise crystal structure and the occupancy of the $\mathrm{Y}(1)$ and the $\mathrm{Y}(2)$ sites for the $\mathrm{SrY}_{2-x} \mathrm{CeO}_{4}(x=0,0.2,1.0)$ samples ${ }^{35}$ From the Rietveld refinement, the following final $R$-factors were obtained: $R_{\text {wp }}$ ( $R$-weighted pattern), $R_{\mathrm{p}}$ (R-pattern), $R_{\mathrm{e}}$ (R-expected), $S$ (goodness-of-fit indicator), and $R_{\mathrm{F}}$ ( $R$-structure factor).

The morphology of the $\mathrm{SrYCeO}_{4}$ particles was investigated by using field-emission-type scanning electron microscopy (FESEM; JEOL, JSM-6701F). The optical reflectance spectra were measured with a UV-vis spectrometer (Shimadzu, UV-2550 with an integrating sphere attachment) with barium sulphate as a reference. The colour properties of the samples were evaluated in terms of the CIE $L^{*} a^{*} b^{*} C h^{\circ}$ system using a chromometer (Konika-Minolta, CR-300). The $L^{*}$ parameter indicates the brightness or darkness of a colour relative to a neutral grey scale, and the $a^{*}$ (the red-green axis) and $b^{*}$ (the yellow-blue axis) parameters express the colour qualitatively. Chroma parameter $(C)$ represents the colour saturation of the pigments and is calculated according to the following formula: $C=\left[\left(a^{*}\right)^{2}\right.$ $\left.+\left(b^{*}\right)^{2}\right]^{1 / 2}$. The parameter $h^{\circ}$ ranges from 0 to $360^{\circ}$, and is calculated with the formula, $h^{\circ}=\tan ^{-1}\left(b^{*} / a^{*}\right)$. X-ray photoelectron spectra measurements (XPS; ULVAC-PHI, PHI5000 VersaProbe II) using $\mathrm{Mg}-\mathrm{K} \alpha$ radiation were carried out to investigate the oxidation state of the cerium ion on the surface of the as-synthesized and the calcined $\mathrm{SrYCeO}_{4}$ samples.

\section{Results and discussion}

\section{$\mathrm{X}$-ray powder diffraction and SEM image}

Fig. 1 shows the XRD patterns of the synthesized $\mathrm{SrY}_{2-x} \mathrm{Ce}_{x} \mathrm{O}_{4}(0$ $\leq x \leq 1.2)$ pigments. All $\mathrm{SrY}_{2-x} \mathrm{Ce}_{x} \mathrm{O}_{4}(0 \leq x \leq 1.2)$ samples were obtained in a single-phase form, and no diffraction peaks of

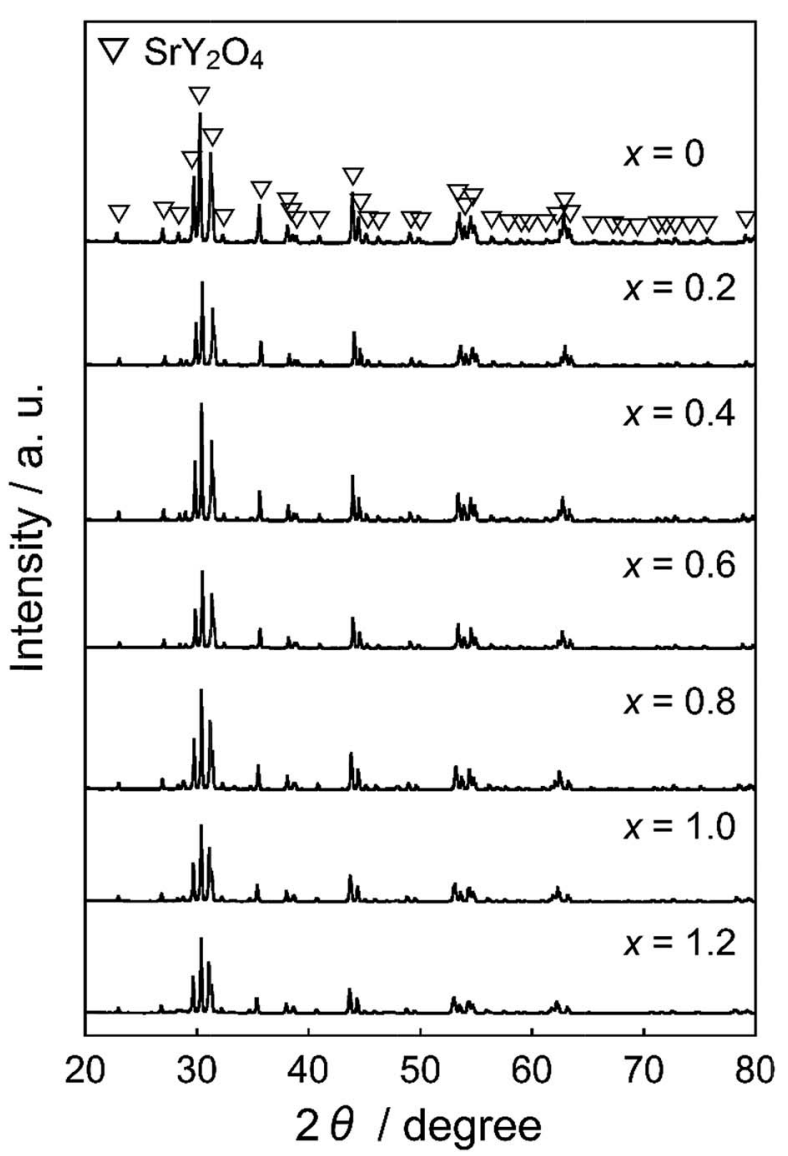

Fig. 1 XRD patterns of the $\mathrm{SrY}_{2-x} \mathrm{Ce}_{x} \mathrm{O}_{4}(\mathrm{O} \leq x \leq 1.2)$ pigments.

impurities or other phases were observed in the patterns. The XRD peaks shifted to lower angle direction with increasing the $\mathrm{Ce}^{3+}$. The lattice volumes of all samples were calculated from the XRD peak angles, and the results are summarized in Table 1 . The cell volume increased with increasing the $\mathrm{Ce}^{3+}$ concentration. These results indicate that $\mathrm{Y}^{3+}$ (ionic radius: $0.104 \mathrm{~nm})^{36}$ ions in the host lattice were partially substituted by larger $\mathrm{Ce}^{3+}(0.115 \mathrm{~nm})^{36}$ ions to form solid solutions.

The Rietveld analysis of the XRD data of the $\mathrm{SrY}_{2-x} \mathrm{CeO}_{4}(x=$ $0,0.2$, and 1.0) samples was carried out to determine the site occupancy of the Y(1) and the Y(2) sites. The Rietveld refinement profiles of the samples are shown in Fig. 2, and the detailed crystallographic data and structure refinement parameters are summarized in Tables 2 and 3, respectively.

Table 1 Lattice volumes of $\mathrm{SrY}_{2-x} \mathrm{Ce}_{x} \mathrm{O}_{4}(0 \leq x \leq 1.2)$

$\mathrm{x}$

0

0.2

0.4

0.6

0.8

1.0

1.2
Lattice volume $/ \mathrm{nm}^{3}$

0.410

0.411

0.413

0.414

0.418

0.420

0.422 

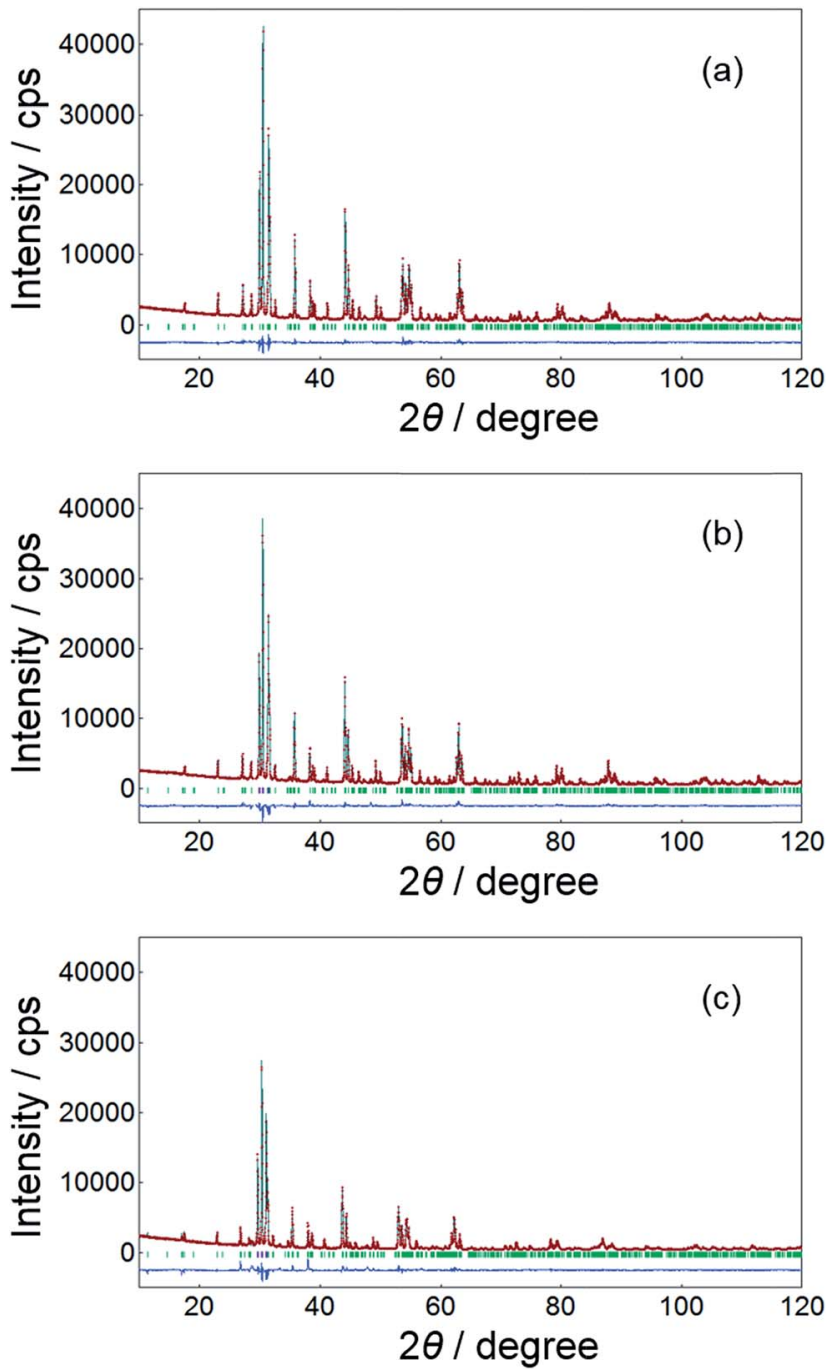

Fig. 2 Observed (red + symbols), calculated (solid line) and difference blue line patterns for the Rietveld refinement from the $X$-ray powder diffraction data of the synthesized $\mathrm{SrY}_{2} \mathrm{O}_{4}$ (a), $\mathrm{SrY}_{1.8} \mathrm{Ce}_{0.2} \mathrm{O}_{4}$ (b) and $\mathrm{SrYCeO}_{4}$ (c).

Table 2 Crystallographic parameters of $\mathrm{SrY}_{2-x} \mathrm{Ce}_{x} \mathrm{O}_{4}(x=0,0.2,1)$ obtained from Rietveld refinement analysis ${ }^{a}$

\begin{tabular}{llll}
\hline & $x=0$ & $x=0.2$ & $x=1$ \\
\hline $\begin{array}{l}\text { Cell data } \\
a(\mathrm{~nm})\end{array}$ & $1.007815(7)$ & $1.008700(5)$ & \\
$b(\mathrm{~nm})$ & $0.340805(2)$ & $0.341514(2)$ & $0.345788(4)$ \\
$c(\mathrm{~nm})$ & $1.191426(8)$ & $1.193350(7)$ & $1.20445(1)$ \\
$V\left(\mathrm{~nm}^{3}\right)$ & $0.409217(5)$ & $0.411091(4)$ & $0.421491(8)$ \\
& & & \\
$R$ factor & & & \\
$R_{\mathrm{wp}}$ & 3.398 & 4.785 & 6.478 \\
$R_{\mathrm{p}}$ & 2.536 & 3.474 & 4.370 \\
$R_{\mathrm{e}}$ & 2.662 & 2.716 & 3.119 \\
$S$ & 1.277 & 1.761 & 2.163 \\
$R_{\mathrm{F}}$ & 1.456 & 3.781 & 3.701
\end{tabular}

${ }^{a}$ Crystal symmetry: orthorhombic, space group: Pnma, number of formula units per unit cell: $Z=4$.
Table 3 Refined structural parameters of $\mathrm{SrY}_{2-x} \mathrm{Ce}_{x} \mathrm{O}_{4}(x=0,0.2,1)$ pigments from Rietveld refinement using XRD data obtained at room temperature $^{a}$

\begin{tabular}{|c|c|c|c|c|c|}
\hline \multicolumn{6}{|c|}{$\mathrm{SrY}_{2} \mathrm{O}_{4}(x=0)^{b}$} \\
\hline Atom & Occupancy & $x$ & $y$ & $z$ & $U_{\text {iso }}\left(\mathrm{nm}^{2}\right)$ \\
\hline $\mathrm{Sr}$ & 1 & $0.24722(9)$ & $1 / 4$ & $0.64940(9)$ & $0.000087(2)$ \\
\hline Y1 & 1 & $0.0775(1)$ & $1 / 4$ & $0.38967(7)$ & $0.000067(3)$ \\
\hline Y2 & 1 & $0.5762(1)$ & $1 / 4$ & $0.61230(7)$ & $0.000086(3)$ \\
\hline $\mathrm{O} 1$ & 1 & $0.2861(5)$ & $1 / 4$ & $0.3235(4)$ & 0.0001303 \\
\hline $\mathrm{O} 2$ & 1 & $0.3729(5)$ & $1 / 4$ & $0.0193(5)$ & 0.0001303 \\
\hline $\mathrm{O} 3$ & 1 & $0.4852(5)$ & $1 / 4$ & $0.7820(4)$ & 0.0001303 \\
\hline $\mathrm{O} 4$ & 1 & $0.07423(6)$ & $1 / 4$ & $0.0767(4)$ & 0.0001303 \\
\hline \multicolumn{6}{|c|}{$\operatorname{SrY}_{1.8} \mathrm{Ce}_{0.2} \mathrm{O}_{4}(x=0.2)^{c}$} \\
\hline Atom & Occupancy & \multicolumn{2}{|l|}{$x$} & $y$ & $z$ \\
\hline $\mathrm{Sr}$ & 1 & 0.2 & $83(1)$ & $1 / 4$ & $0.64917(1)$ \\
\hline Y1 & $0.84(1)$ & 0.0 & $72(1)$ & $1 / 4$ & $0.3891(1)$ \\
\hline Y2 & 0.96 & 0.5 & $80(2)$ & $1 / 4$ & $0.6125(1)$ \\
\hline Ce1 & 0.16 & 0.0 & & $1 / 4$ & 0.3891 \\
\hline $\mathrm{Ce} 2$ & 0.04 & 0.5 & & $1 / 4$ & 0.6125 \\
\hline O1 & 1 & 0.2 & $71(8)$ & $1 / 4$ & $0.3236(7)$ \\
\hline $\mathrm{O} 2$ & 1 & 0.3 & $42(7)$ & $1 / 4$ & $0.0188(7)$ \\
\hline $\mathrm{O} 3$ & 1 & 0.4 & $22(8)$ & $1 / 4$ & $0.7832(6)$ \\
\hline $\mathrm{O} 4$ & 1 & 0.0 & $8(1)$ & $1 / 4$ & $0.0770(6)$ \\
\hline \multicolumn{6}{|c|}{$\mathrm{SrYCeO}_{4}(x=1)^{c}$} \\
\hline Atom & Occupancy & \multicolumn{2}{|l|}{$x$} & $y$ & $z$ \\
\hline $\mathrm{Sr}$ & 1 & \multicolumn{2}{|c|}{$0.2509(3)$} & $1 / 4$ & $0.6482(2)$ \\
\hline Y1 & $0.36(1)$ & \multicolumn{2}{|c|}{$0.0746(2)$} & $1 / 4$ & $0.3880(2)$ \\
\hline Y2 & 0.64 & \multicolumn{2}{|c|}{$0.5844(3)$} & $1 / 4$ & $0.6118(2)$ \\
\hline Ce1 & 0.64 & \multicolumn{2}{|c|}{0.0746} & $1 / 4$ & 0.0746 \\
\hline $\mathrm{Ce} 2$ & 0.36 & \multicolumn{2}{|c|}{0.5844} & $1 / 4$ & 0.5844 \\
\hline $\mathrm{O} 1$ & 1 & \multicolumn{2}{|c|}{$0.278(2)$} & $1 / 4$ & $0.319(1)$ \\
\hline $\mathrm{O} 2$ & 1 & \multicolumn{2}{|c|}{$0.374(1)$} & $1 / 4$ & $0.012(2)$ \\
\hline $\mathrm{O} 3$ & 1 & \multicolumn{2}{|c|}{$0.487(1)$} & $1 / 4$ & $0.787(1)$ \\
\hline $\mathrm{O} 4$ & 1 & \multicolumn{2}{|c|}{$0.086(2)$} & $1 / 4$ & $0.079(1)$ \\
\hline
\end{tabular}

${ }^{a}$ All atoms are placed at general $4 \mathrm{c}$ positions. ${ }^{b}$ At refinement of $\mathrm{SrY}_{2} \mathrm{O}_{4}$, isotropic atomic displacement parameters $\left(U_{\text {iso }}\right)$ of four oxygen atoms were constrained to be equal. ${ }^{c}$ Because of the disordering of $\mathrm{Y}$ and Ce atoms, the fractional coordinate and $U_{\text {iso }}$ were constraint to the same values, respectively. In order to refine the occupation ratio of $\mathrm{Ce}$ atoms, $U_{\text {iso }}$ parameters of $\mathrm{Sr}, \mathrm{Y}$ and $\mathrm{O}$ atoms were fixed to the respective values of each atoms at non-doped $\mathrm{SrY}_{2} \mathrm{O}_{4}$.

Fig. 3 shows the crystal structure of $\mathrm{SrY}_{2} \mathrm{O}_{4}$ illustrated using the VESTA program based on the crystallographic data from the Rietveld refinement. ${ }^{37}$ As seen in Table 2, the low $R$-factors were obtained for all the $\mathrm{SrY}_{2-x} \mathrm{Ce}_{x} \mathrm{O}_{4}(x=0,0.2$, and 1.0) samples. The Rietveld refinements revealed that the $\mathrm{Ce}^{3+}$ concentrations at the $\mathrm{Y}(1)$ site gradually increased from 16 to $64 \mathrm{~mol} \%$, while that in the $\mathrm{Y}(2)$ site increased from 4 to $36 \mathrm{~mol} \%$ as $x$ increased from 0.2 to 1, as seen in Table 3. Therefore, in the $\mathrm{SrY}_{2-x} \mathrm{Ce}_{x} \mathrm{O}_{4}$ structure, $\mathrm{Ce}^{3+}$ ions occupied both $\mathrm{Y}(1)$ and $\mathrm{Y}(2)$ sites. Although each Y site is coordinated by six oxide anions, one $\mathrm{Y}(1)$ site is located in the ideal octahedral coordination environment and the other $\mathrm{Y}(2)$ site is significantly distorted, as shown in Fig. 3. This difference of structural distortion of two non-equivalent $\mathrm{Y}$ 
(a)

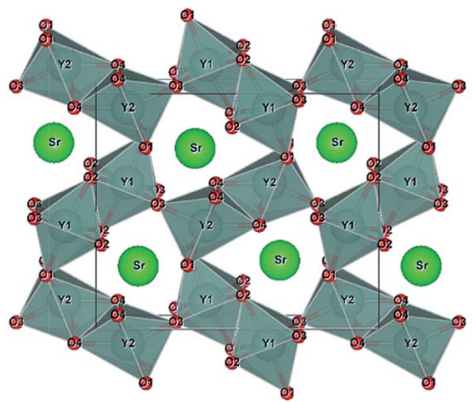

(b)
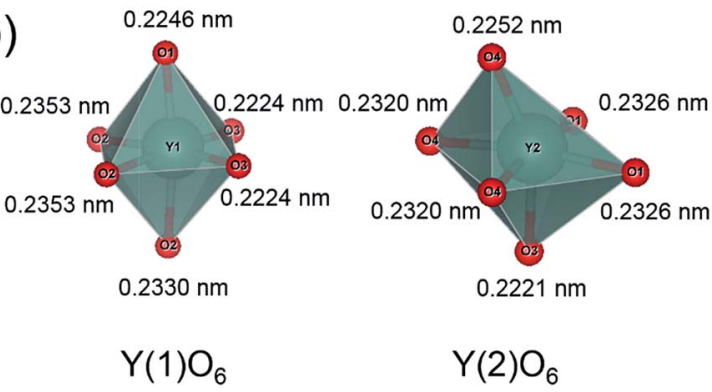

Fig. 3 Crystal structure obtained by the Rietveld analysis for $\mathrm{SrY}_{2} \mathrm{O}_{4}$ (a), and the octahedral coordination environment of $\mathrm{Y}(1) \mathrm{O}_{6}$ and $\mathrm{Y}(2) \mathrm{O}_{6}$ in $\mathrm{SrY}_{2} \mathrm{O}_{4}$ (b).

sites affects the $\mathrm{Ce}^{3+}$ occupancy. In fact, the occupancy ratio, $\mathrm{Ce} 2 / \mathrm{Ce} 1$, was 0.25 for $\mathrm{SrY}_{1.8} \mathrm{Ce}_{0.2} \mathrm{O}_{4}(x=0.2)$, while it was 0.56 for $\mathrm{SrYCeO}_{4}(x=1)$. These results indicate that the $\mathrm{Ce}^{3+}$ ions were preferentially located in the energetically favoured ideal octahedral $\mathrm{Y}(1)$ site when the $\mathrm{Ce}^{3+}$ concentration was low, and suggest that the distorted $\mathrm{Y}(2)$ site were also begun to be occupied when the $\mathrm{Ce}^{3+}$ concentration was increased and the solubility in the $\mathrm{Y}(1)$ sites were saturated.

Fig. 4 shows the FE-SEM images of the $\mathrm{SrYCeO}_{4}(x=1)$ sample at different magnifications. Since it was synthesized at a high temperature of $1300{ }^{\circ} \mathrm{C}$, the primary particles melted to form large secondary particles.

\section{Reflectance spectra}

The UV-vis reflectance and absorption spectra of $\mathrm{SrY}_{2-x} \mathrm{Ce}_{x} \mathrm{O}_{4}(0$ $\leq x \leq 1.2)$ are depicted in Fig. 5 . The absorbance spectra were represented by the Kubelka-Munk function, $f(R)=(1-R)^{2} / 2 R$, where $R$ is reflectance. ${ }^{38}$ The non-doped $\operatorname{SrY}_{2} \mathrm{O}_{4}$ sample showed high reflectance in the visible light region of 400 to $750 \mathrm{~nm}$. In the case of the $\mathrm{Ce}^{3+}$-doped $\mathrm{SrY}_{2-x} \mathrm{Ce}_{x} \mathrm{O}_{4}(0.2 \leq x \leq 1.2)$ samples, on the other hand, optical absorption were observed due to the $\mathrm{O}_{2 \mathrm{p}}-\mathrm{Ce}_{4 \mathrm{f}}$ charge transfer transition at a wavelength of $380 \mathrm{~nm}$ or shorter as well as the $4 \mathrm{f}-5 \mathrm{~d}$ allowed transition of $\mathrm{Ce}^{3+}$ in the wavelength range from violet to green $(400-550 \mathrm{~nm}) \cdot{ }^{28-30,39} \mathrm{As}$ the concentration of $\mathrm{Ce}^{3+}$ increased, the absorption due to the $4 \mathrm{f}-5 \mathrm{~d}$ transition appeared more intensely. In addition, the reflectance at $600 \mathrm{~nm}$ and longer wavelengths also decreased when the $\mathrm{Ce}^{3+}$ concentration became high.

These results are considered to be due to the existence of two non-equivalent octahedral $\mathrm{Y}$ sites of different coordination environments in the crystal structure of $\mathrm{SrY}_{2} \mathrm{O}_{4}$. As mentioned
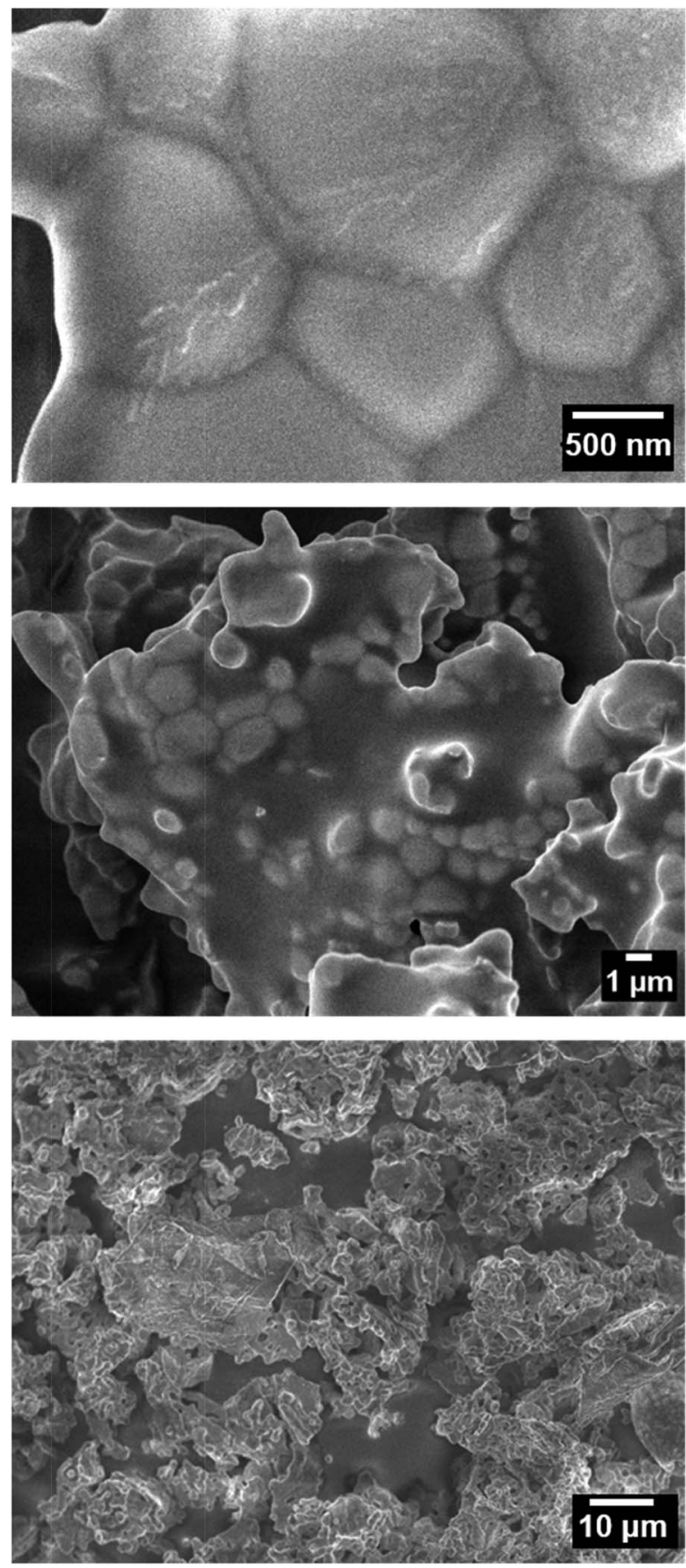

Fig. 4 FE-SEM images of $\mathrm{SrYCeO}_{4}(x=1)$ at different magnifications.

above, $\mathrm{Y}(1)$ site is located in the ideal octahedral coordination environment and the other Y(2) site is significantly distorted, ${ }^{31}$ as illustrated in Fig. 3. The band structure models of the ideal $\mathrm{Y}(1)$ and the distorted $\mathrm{Y}(2)$ sites in the $\mathrm{SrY}_{2-x} \mathrm{Ce}_{x} \mathrm{O}_{4}(0 \leq x \leq 1.2)$ samples are illustrated schematically in Fig. 6 . The valence band (VB) and the conduction band (CB) consist of $\mathrm{O}_{2 \mathrm{p}}$ and $\mathrm{Y}_{3 \mathrm{~d}}$ orbitals, respectively. When the $\mathrm{Ce}^{3+}$ ions are doped into the $\mathrm{SrY}_{2} \mathrm{O}_{4}$ lattice, the $4 \mathrm{f}$ and $5 \mathrm{~d}$ energy levels of $\mathrm{Ce}^{3+}$ are introduced between VB $\left(\mathrm{O}_{2 \mathrm{p}}\right.$ orbital) and $\mathrm{CB}\left(\mathrm{Y}_{3 \mathrm{~d}}\right.$ orbital). Since the crystal field energy around the $\mathrm{Ce}^{3+}$ ions in the distorted $\mathrm{Y}(2)$ site is stronger than that in the ideal $\mathrm{Y}(1)$ site, the $5 \mathrm{~d}$ orbital energy 

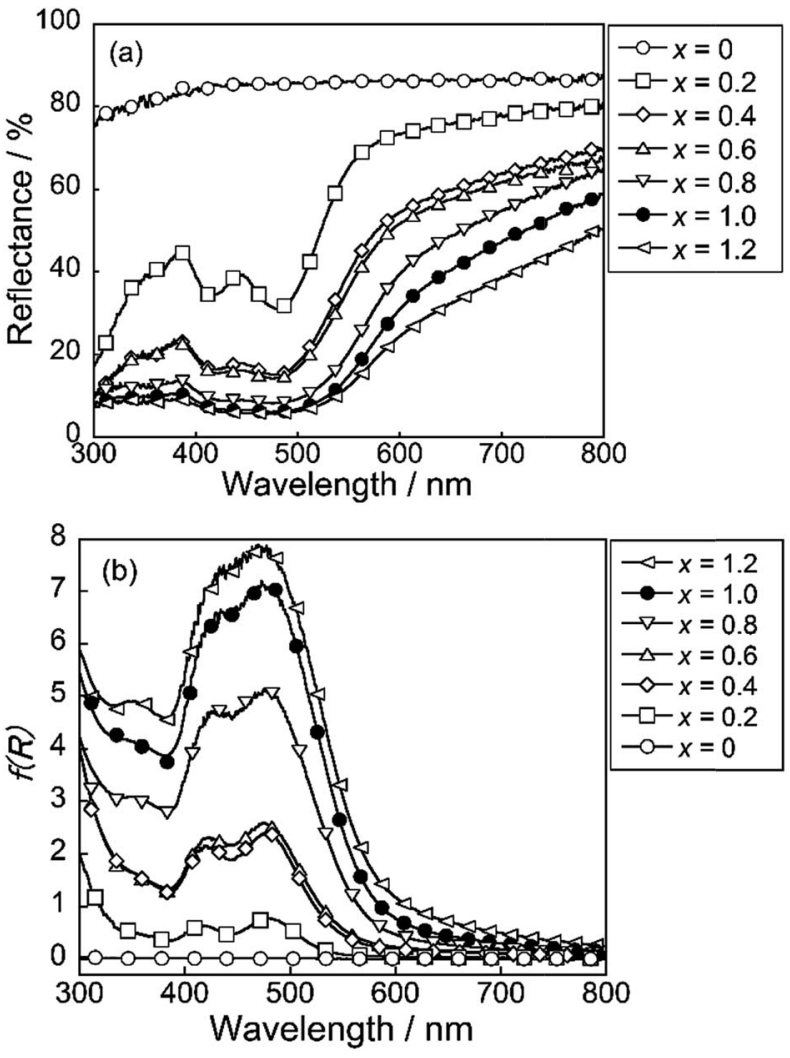

Fig. 5 UV-vis reflectance (a) and absorption (b) spectra of $\mathrm{SrY}_{2-x^{-}}$ $\mathrm{Ce}_{x} \mathrm{O}_{4}(0 \leq x \leq 1.2)$.

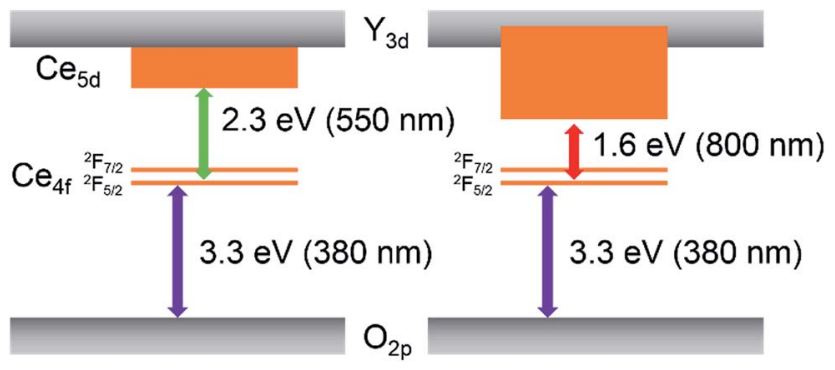

(a)

(b)

Fig. 6 Band structure models of the ideal octahedral $Y(1)$ site (a) and the distorted $\mathrm{Y}(2)$ site $(\mathrm{b})$ in the $\mathrm{SrY}_{2-x} \mathrm{Ce}_{x} \mathrm{O}_{4}(0 \leq x \leq 1.2)$ pigments.

splitting of $\mathrm{Ce}^{3+}$ in the $\mathrm{Y}(2)$ site is also larger than that in the $\mathrm{Y}(1)$ site. As already discussed, the $\mathrm{Ce}^{3+}$ preferentially occupies the ideal $\mathrm{Y}(1)$ in the low $\mathrm{Ce}^{3+}$ concentration sample, and the $\mathrm{Y}(2)$ occupancy was increased with increasing the $\mathrm{Ce}^{3+}$ concentration.

Accordingly, the optical absorption at $600 \mathrm{~nm}$ and longer wavelengths was observed in the samples with high $\mathrm{Ce}^{3+}$ concentration.

\section{Chromatic properties}

The chromatic parameters of the synthesized $\mathrm{SrY}_{2-x} \mathrm{Ce}_{x} \mathrm{O}_{4}(0 \leq$ $x \leq 1.2$ ) pigments are summarized in Table 4 . The photographs
Table 4 Chromatic properties of $\mathrm{SrY}_{2-x} \mathrm{Ce}_{x} \mathrm{O}_{4}(0 \leq x \leq 1.2)$

\begin{tabular}{llllll}
\hline$x$ & $L^{*}$ & $a^{*}$ & $b^{*}$ & $C$ & $h^{\circ}$ \\
\hline 0 & 98.2 & -0.24 & +1.69 & 1.71 & 98.1 \\
0.2 & 83.3 & +1.78 & +36.3 & 36.3 & 87.2 \\
0.4 & 68.6 & +10.2 & +45.3 & 46.4 & 77.3 \\
0.6 & 68.4 & +10.5 & +43.3 & 44.6 & 76.4 \\
0.8 & 57.3 & +20.4 & +44.1 & 48.6 & 65.2 \\
1.0 & 49.1 & +21.8 & +42.2 & 47.5 & 62.7 \\
1.2 & 42.8 & +19.7 & +36.5 & 41.5 & 61.6
\end{tabular}

of these pigments are also displayed in Fig. 7. The $L^{*}$ values increased as the amount of $\mathrm{Ce}^{3+}$ decreased. The $a^{*}$ and $b^{*}$ values increased in a positive direction. As already discussed above regarding the results in Fig. 3, these relationships can be attributed to the difference of coordination environment around the $\mathrm{Ce}^{3+}$ ions. When the $\mathrm{Ce}^{3+}$ concentration is relatively low, the $\mathrm{Ce}^{3+}$ ions are preferentially located in the ideal octahedral $\mathrm{Y}(1)$ site. Since the crystal field of $\mathrm{Ce}^{3+}$ in the $\mathrm{Y}(1)$ site is relative small, the $4 \mathrm{f}-5 \mathrm{~d}$ allowed transition of $\mathrm{Ce}^{3+}$ in this site is observed at the wavelengths in the region of violet to blue green $(400-550 \mathrm{~nm})$. As a result, the samples are yellow, which is complementary colour of blue. On the other hand, the samples containing $\mathrm{Ce}^{3+}$ at high concentrations additionally absorbed light at wavelengths of $600 \mathrm{~nm}$ and above, corresponding to the $4 \mathrm{f}-5 \mathrm{~d}$ allowed transition of $\mathrm{Ce}^{3+}$ in the distorted octahedral $\mathrm{Y}(2)$ site. Accordingly, the samples gradually became reddish with increasing the $\mathrm{Ce}^{3+}$ content. Among the $\mathrm{SrY}_{2-x} \mathrm{Ce}_{x} \mathrm{O}_{4}$ samples synthesized in this study, $\mathrm{SrYCeO}_{4}$ is the most reddish $\left(a^{*}=\right.$ +21.8 ).

\section{Thermal and chemical stability tests}

The thermal and chemical stabilities of the $\mathrm{SrYCeO}_{4}$ pigment were evaluated using the powder sample. To evaluate the thermal stability, this sample was heated in a mullite crucible at $300{ }^{\circ} \mathrm{C}$ and $500{ }^{\circ} \mathrm{C}$ for $3 \mathrm{~h}$ under an air atmosphere and cooled to room temperature. The acid/base resistance of the $\mathrm{SrYCeO}_{4}$ pigment was tested in $4 \%$ acetic acid and $4 \%$ ammonium bicarbonate solutions, and the pigment was dispersed into the acid/base solutions. After leaving them at room temperature for

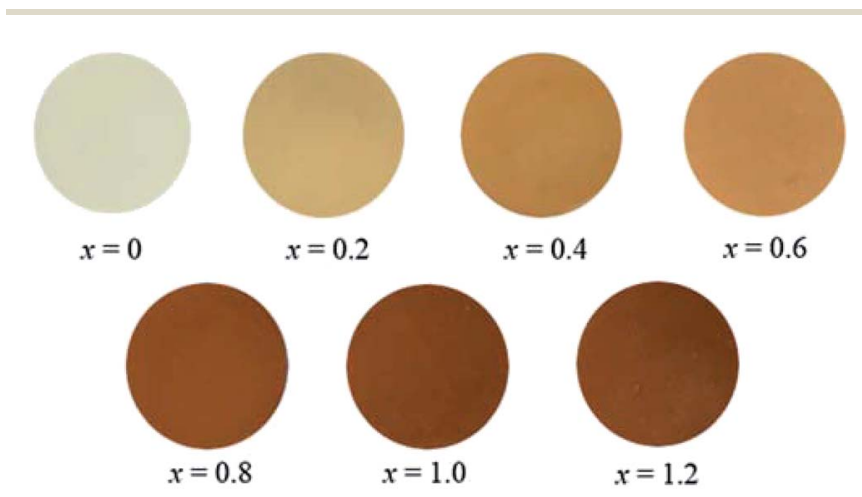

Fig. 7 Photographs of the $\mathrm{SrY}_{2-x} \mathrm{Ce}_{x} \mathrm{O}_{4}(0 \leq x \leq 1.2)$ pigments. 
$1 \mathrm{~h}$, the sample was washed with deionized water and ethanol, and then dried at room temperature.

The colour of the samples after the thermal and chemical stability tests were evaluated using the colorimeter. The colour coordinate data are summarized in Table 5. Unfortunately, the heat resistance of this sample was low, and the colour degradation was observed after heating the present $\mathrm{SrYCeO}_{4}$ pigment at $300{ }^{\circ} \mathrm{C}$ and above in air. On the other hand, the $\mathrm{SrYCeO}_{4}$ pigment has chemical stability. The colour was almost unchanged after the leaching test in the acetic acid and ammonium bicarbonate solutions.

In order to investigate the reason for the color degradation after the heating in air, oxidation state of the cerium ions of the $\mathrm{SrYCeO}_{4}$ samples was identified by the XPS measurement before and after the heat resistance tests. The $\mathrm{Ce}\left(3 \mathrm{~d}_{3 / 2}\right)$ and Ce $\left(3 d_{5 / 2}\right)$ XPS obtained from the $\mathrm{SrYCeO}_{4}$ sample before and after the heat resistance tests are shown in Fig. 8. In addition to the binding energy peaks for $\mathrm{Ce}^{3+}$ at $884.2\left(\mathrm{~V}^{\prime}\right)$ and $902.4\left(\mathrm{U}^{\prime}\right) \mathrm{eV}$, four peaks corresponding to $\mathrm{Ce}^{4+}$ species on the surface of the non-treatment sample were observed at $881.1(\mathrm{~V}), 897.4\left(\mathrm{~V}^{\prime \prime \prime}\right)$, $899.8(\mathrm{U})$ and $914.5\left(\mathrm{U}^{\prime \prime \prime}\right) \mathrm{eV} .^{\mathbf{4 0 , 4 1}}$ The labels $\mathrm{U}$ and $\mathrm{V}$ refer to the Ce $\left(3 d_{3 / 2}\right)$ and Ce $\left(3 d_{5 / 2}\right)$ spin-orbit components. The intensities of two peaks assigned to $\mathrm{Ce}^{3+}$ decreased with increasing the calcination temperature, in comparison with those of the assynthesized sample. Therefore, the colour degradation will be caused by the oxidation of $\mathrm{Ce}^{3+}$ to $\mathrm{Ce}^{4+}$.

Table 5 Colour coordinates of $\mathrm{SrYCeO}_{4}$ before and after thermal and chemical stability tests

\begin{tabular}{lccccc}
\hline Pigment & $L^{*}$ & $a^{*}$ & $b^{*}$ & $C$ & $h^{\circ}$ \\
\hline As synthesized & 49.1 & +21.8 & +42.2 & 47.5 & 62.7 \\
$300{ }^{\circ} \mathrm{C}$ in air & 94.5 & -0.33 & +3.12 & 3.14 & 96.0 \\
$500{ }^{\circ} \mathrm{C}$ in air & 95.4 & -0.94 & +3.41 & 3.54 & 105 \\
$4 \% \mathrm{CH}_{3} \mathrm{COOH}$ & 49.3 & +17.5 & +41.1 & 44.7 & 66.9 \\
$4 \% \mathrm{NH}_{4} \mathrm{HCO}_{3}$ & 46.7 & +18.7 & +40.6 & 44.7 & 65.3
\end{tabular}

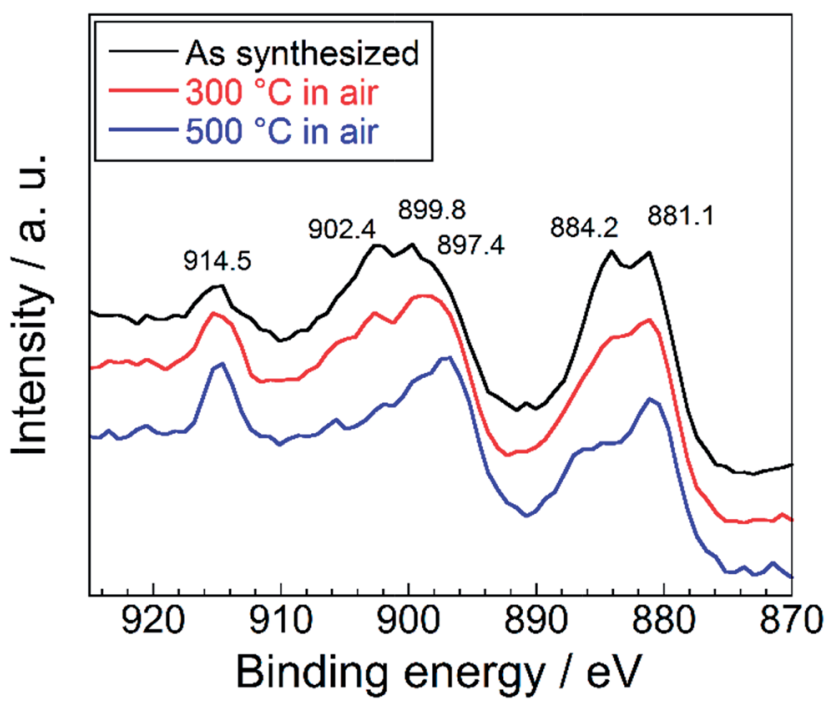

Fig. $8 \mathrm{Ce}(3 \mathrm{~d}) \mathrm{XPS}$ for $\mathrm{SrYCeO}_{4}$ samples before and after heat resistance test.

\section{Conclusions}

$\mathrm{SrY}_{2-x} \mathrm{Ce}_{x} \mathrm{O}_{4}(0 \leq x \leq 1.2)$ were synthesized using a citrate solgel method as environmentally friendly inorganic reddishbrown pigments. The samples exhibited optical absorption due to the $4 \mathrm{f}-5 \mathrm{~d}$ allowed transition of $\mathrm{Ce}^{3+}$ at wavelengths from 410 to $500 \mathrm{~nm}$ and at $600 \mathrm{~nm}$ and longer. The former is attributed to the $4 \mathrm{f}-5 \mathrm{~d}$ transition of $\mathrm{Ce}^{3+}$ in the ideal octahedral $\mathrm{Y}(1)$ site, and the latter is due to that in the distorted octahedral $\mathrm{Y}(2)$ site. Since the $\mathrm{Ce}^{3+}$ ions were preferentially dissolved into the energetically favoured Y(1) site, the colour of the samples gradually changed from yellow to reddish brown with increasing the $\mathrm{Ce}^{3+}$ concentration. The most reddish colour was observed for $\mathrm{SrYCeO}_{4}\left(a^{*}=+21.8\right)$. Since this compound is consisted with non-toxic elements, it is expected to be an environmentally friendly inorganic reddish-brown pigment.

\section{Conflicts of interest}

There are no conflicts to declare.

\section{Acknowledgements}

This work was partially supported by JSPS KAKENHI Grant Number 15K05643. The authors thank Dr Hirokazu Izumi (Hyogo Prefectural Institute of Technology) for his assistance with X-ray photoelectron spectroscopy measurements.

\section{References}

1 K. Těšitelová and P. Šulcová, J. Therm. Anal. Calorim., 2016, 125, 1047.

2 T. Tsukimori, R. Oka and T. Masui, Dyes Pigm., 2017, 139, 808.

3 K. Kusumoto, J. Ceram. Soc. Jpn., 2016, 124, 926.

4 T. Masui, T. Honda, Wendusu and N. Imanaka, Dyes Pigm., 2013, 99, 636.

5 B. Bae, Wendusu, S. Tamura and N. Imanaka, Ceram. Int., 2016, 42, 15104.

6 Wendusu, T. Honda, T. Masui and N. Imanaka, Chem. Lett., 2013, 42, 1562.

7 J. Grins and G. Svensson, Mater. Res. Bull., 1994, 29, 801.

8 S. Furukawa, T. Masui and N. Imanaka, J. Alloys Compd., 2006, 418, 255.

9 S. Furukawa, T. Masui and N. Imanaka, J. Alloys Compd., 2008, 451, 640.

10 M. Martos, B. Julián-López, E. Cordoncillo and P. Escribano, J. Am. Ceram. Soc., 2009, 92, 2987.

11 S. P. Radhika, K. J. Sreeram and B. U. Nair, ACS Sustainable Chem. Eng., 2014, 2, 1251.

12 M. Llusar, E. García, M. T. García, C. Gargori, J. A. Badenes and G. Monrós, Dyes Pigm., 2015, 122, 368.

13 G. George, Dyes Pigm., 2015, $122,81$.

14 A. K. V. Raj, P. P. Rao, S. Sameera, V. James and S. Divya, Chem. Lett., 2014, 43, 985.

15 A. K. V. Raj, P. P. Rao, S. Divya and T. R. Ajuthara, Powder Technol., 2017, 311, 52. 
16 V. D. Luz, M. Prades, H. Beltrán and E. Cordoncillo, J. Eur. Ceram. Soc., 2013, 33, 3359.

17 N. Pailhé, M. Gaudon and A. Demourgues, Mater. Res. Bull., 2009, 44, 1771.

18 M. Jansen and H. P. Letschert, Nature, 2000, 404, 27.

19 P. Maestro and D. Huguenin, J. Alloys Compd., 1995, 225, 520.

20 Wendusu, A. Shiraishi, N. Takeuchi, T. Masui and N. Imanaka, RSC Adv., 2015, 5, 44886.

21 E. Guenther and M. Jansen, Mater. Res. Bull., 2001, 36, 1399.

22 H. Saal, M. Binnewies, M. Schrader, A. Börger, K. Becker, V. A. Tikhomirov and K. Jug, Chem.-Eur. J., 2009, 15, 6408.

23 Wendusu, T. Yoshida, T. Masui and N. Imanaka, J. Adv. Ceram., 2015, 4, 39.

24 L. S. Kumari, P. P. Rao, S. Sameera and P. Koshy, Ceram. Int., 2012, 38, 4009.

25 S. W. Kim, T. Hasegawa, M. Watanabe, K. Sugimoto, Y. Saito, K. Uematsu, K. Toda and M. Sato, Dyes Pigm., 2017, 136, 219.

26 S. Radhika, K. J. Sreeram and B. U. Nair, J. Chem. Sci., 2014, 126, 65.

27 M. Jovaní, A. Sanz, H. Beltrán-Mir and E. Cordoncillo, Dyes Pigm., 2016, 133, 33.

28 V. Bachmann, C. Ronda and A. Meijerink, Chem. Mater., 2009, 21, 2077.
29 P. Schlotter, R. Schmidt and J. Schneider, Appl. Phys. A, 1997, 64, 417.

30 Y. Pan, M. Wu and Q. Su, Mater. Sci. Eng., B, 2004, 106, 251. 31 V. H. Müller-Buschbaum, Z. Anorg. Allg. Chem., 1968, 358, 138.

32 Z. Fu, S. Zhou, Y. Yu and S. Zhang, J. Phys. Chem. B, 2005, 109, 23320.

33 V. Manivannan, H. A. Comanzo, A. A. Setlur, A. M. Srivastava, P. A. Schmidt and U. Happek, J. Lumin., 2003, 102, 635.

34 V. Dubey, J. Kaur, R. Tiwari, Y. Parganiha, R. Srivastava and K. V. R. Murthy, International Journal of Luminescence and Applications, 2015, 5, 211.

35 F. Izumi and K. Momma, Solid State Phenom., 2007, 130, 15. 36 R. D. Shannon, Acta Crystallogr., Sect. A: Cryst. Phys., Diffr., Theor. Gen. Crystallogr., 1976, 32, 751.

37 K. Momma and F. Izumi, J. Appl. Crystallogr., 2011, 44, 1272. 38 P. Kubelka and F. Munk, Z. Tech. Phys., 1931, 12, 593.

39 F. Goubin, X. Rocquefelte, M. Whangbo, Y. Montardi, R. Brec and S. Jobic, Chem. Mater., 2004, 16, 662.

40 D. R. Mullius, S. H. Overbury and D. R. Huntley, Surf. Sci., 1998, 409, 307.

41 J. P. Holgado, G. Muneura, J. P. Espinos and A. R. GonzálezElipe, Appl. Surf. Sci., 2000, 158, 164. 